\title{
Resúmenes Tesis: Maestría en Didáctica de las Ciencias Experimentales
}

\section{Enseñanza de la anatomía orientada al desarrollo de competencias en la carrera de bioingeniería}

\author{
Liliana Alelí Castañeda \\ castaedaliliana@gmail.com \\ Director / Co-Director: Dra. Costamagna, \\ Alicia María Teresa \\ Lugar de realización: Cátedra de Histología \\ y Anatomía. Facultad de Ingeniería. Univer- \\ sidad Nacional de Entre Ríos. Oro Verde, \\ Entre Ríos. \\ Fecha de la defensa: 27/10/2015
}

\section{Resumen}

La enseñanza por competencias, surge como una alternativa de enseñanza tendiente a la superación del aprendizaje puramente memorístico hacia uno más profundo y funcional. Este trabajo se desarrolló sobre la base de entender las competencias como capacidades complejas, que integran saberes teóricos, procedimentales y del contexto, y que permiten adquirir y aplicar distintos saberes en el ámbito académico. Se propuso investigar el valor de una intervención didáctica orientada al estímulo de competencias del área Biológica, en la carrera de Bioingeniería, con la hipótesis que, la enseñanza orientada al desarrollo de competencias en el área Biológica favorece el aprendizaje disciplinar comprensivo, posible de aplicarse a nuevas situaciones, a la vez que contribuye a mejorar el rendimiento académico de los estudiantes. Para esta investigación se utilizaron metodologías cuantitativa y cualitativa, dado que éstas se complementan para abarcar distintos aspectos del objeto de estudio. Se seleccionaron las competencias académicas específicas para el aprendizaje de la Anatomía e Histología Humanas, cuyo desarrollo es necesario incentivar en los estudiantes, para su disponibilidad permanente. Se establecieron sus indicadores y niveles de logro. Se diseñaron y aplicaron las estrategias didácticas orientadas al desarrollo de las competencias. El análisis de la información obtenida de la experiencia realizada, muestra que: los estudiantes tuvieron una opinión favorable sobre la experiencia, se favoreció el aprendizaje comprensivo, los aprendizajes logrados estuvieron disponibles y fueron posibles de aplicar a nuevas situaciones y que esta forma de enseñanza, orientada al desarrollo de competencias, contribuyó positivamente a mejorar el rendimiento académico de los estudiantes.

\section{Summary}

Orienting the teaching of anatomy towards skills development in the career of bioingeneering.

Competence-based learning constitutes a teaching alternative that aims at overcoming rote learning and moving towards deeper and more functional ways of learning. This work was developed under the premise of gaining an understanding of competences as complex capabilities, which integrate theoretical, procedural, and 
contextual knowledge, and that allow for the acquisition and application of different sorts of knowledge in the academic environment. The purpose of this study was to investigate the relevance that a didactic intervention aiming at fostering competences in the field of Biology might have in Bioengineering, hypothesizing that the development of such competences favours more rounded knowledge of the field, understandable, and transferable to new situations, while contributing to the improvement the academic performance of the learners. To this end, both quantitative and qualitative methodologies were employed, given that these can complement each other in order to look at the subject under study from different per- spectives. Specific academic competences for Anatomy and Human Histology were selected, competences whose development must be fostered for these to be permanently available to students. Indicators and achievement levels were established. Didactic strategies aiming at competence development were designed and applied. The analysis of the data collected from the experience indicates that: learners show a favourable attitude towards the experience itself; a more comprehensive form of learning was fostered; the learning outcomes achieved were available and applicable to new situations; and that this competence-based teaching methodology positively contributed to improving learner academic attainment.

\section{Análisis de la aplicación de un programa de acompañamiento didáctico para el mejoramiento de la enseñanza de las ciencias naturales}

\section{Maria Arazunu Martinez}

marazunu@hotmail.com, arazunu@curuzu. net

Directora: Dra. Aurora Cristina Armúa de Reyes

acarmua@hotmail.com

Co-directora: Mgter. María Teresa Alcalá mtalcala@gmail.com

Laboratorio No 2- Departamento de Biología. Facultad DE Ciencias Exactas, Naturales y Agrimensura. Universidad Nacional del Nordeste. Corrientes, Capital.

Fecha de defensa: 21 de agosto de 2015

\section{Resumen}

Este trabajo se enmarca dentro de un Programa Nacional Ilamado "Acompañamiento Didáctico para el Fortalecimiento de la Enseñanza de las Ciencias Naturales" que comenzó a aplicarse en algunas ciudades de la provincia de Corrientes en el año 2008 y llegó a la ciudad de Curuzú Cuatiá en el año 2010. Las acciones de formación que se incluyen en el dispositivo tienen como rasgo central los procesos de asesoramiento a los docentes que enseñan en el segundo ciclo de la escuela primaria. En este sentido, se genera un espacio de intercambio y reflexión sobre las prácticas de enseñanza que se dan en las aulas. Esto se implementa a partir de la lectura de los Cuadernos para el Aula y el asesoramiento sobre los temas que los docentes consideren necesarios para llevar adelante sus propuestas de trabajo. La meta que se propone este Programa es la mejora de la calidad 
de la enseñanza de las Ciencias Naturales, además de generar conocimiento teórico de la situación local, que pueda orientar el desarrollo de nuevas experiencias y crear condiciones que favorezcan los propios procesos de formación docente. A través de la aplicación de este dispositivo es esperable que se produzca un impacto que a largo plazo promueva el mejoramiento de los procesos de enseñanza y aprendizaje de las ciencias naturales.

\section{Summary}

Analysis of the implementation of a mentoring in natural sciences teaching program

The scope of this investigation is defined by the National Program called "Mentoring in Natural Sciences Teaching" which was implemented in some cities in the province of Corrientes in 2008, and started to be implemented in Curuzú Cuatiá in 2010.
The training activities included in the system have as central feature the tutorial guidance given to teachers who teach in the second cycle of primary school. In this sense, there is a space for exchange and discussion about teaching practices in the classroom. The system is implemented through the reading of Classroom Books and guidance on issues that teachers consider necessary to carry out their working proposals. The Program aims to improve the quality of the teaching of Natural Sciences, as well as generate theoretical knowledge of the local situation to guide the development of new experiences and create conditions that foster teacher training processes. It would be expected that the implementation of this system might have an impact in the long term, promoting the improvement of Natural Sciences teaching and learning processes. 